\title{
Exploring the Interaction of Self Narratives with Other Perception - Relevance for Managerial Anthropology and Business Ethics
}

\author{
Kemi Ogunyemi \\ Omowumi Ogunyemi
}

\author{
Lagos Business School, Lagos, Nigeria; \\ Pontifical University of the Holy Cross, Rome, Italy \\ kogunyemi@Ibs.edu.ng; mollyogunyemi@gmail.com
}

\section{Doi:10.5901/mjss.2013.v4n10p179}

\begin{abstract}
Narrative self understanding is becoming more prominent as a field of research in human behaviour, and is particularly interesting for business ethicists who wish to look into behavioural ethics. The way a person possesses his own story can affect his perception of others and his understanding of what is due to them from him. It can therefore affect his capacity to treat them with justice and fairness. This paper looks at the self narratives of twenty subjects vis-à-vis their perceptions of a common event (as a proxy of their judgements of others which therefore would influence their relations with others). It thus uses a qualitative method of textual analysis to examine the relationship between the way a person perceives and describes himself or herself and the way he or she perceives others. The study throws light on an important aspect that needs to be included in curricula of managerial anthropology and of business ethics.
\end{abstract}

Keywords: Self narratives, self understanding, other-perception, business ethics, managerial anthropology

\section{Introduction}

Many current philosophical trends state that a human being's actions may be evaluated within the perspective of his narrative; looking at the type of autobiography he is trying to build up. Narrative self understanding is beoming more prominent as a field of research in human behaviour, and is particularly interesting for business ethicists who wish to look into behavioural ethics. The way a person views and directs his own story can affect his perception of others and his understanding of what is due to them from him. It can therefore affect his capacity to treat them with justice and fairness.

The philosophical concept of the self narrative understanding and the construction of a personal narrative identity with the actions and choices made are applicable to actions performed within organisations and in business organisations. This is possible when one considers that a global development of the person seeking happiness involves all his free actions and how he lets his actions be orientated by his overall goals forming a coherent purposeful narrative of his life. A narrative vision of life integrates into a single unit the past, the present and the future of the human being. ${ }^{1}$ With narrative self-understanding, one can avoid compartmentalisation of ambits of life which could lead to a loss of the benefits which a global vision of each action situated within the autobiography could give. One would be able to evaluate the morality of individual actions within the true context of a whole life. After all, a business leader is primarily a human person is writing his personal narrative and seeks happiness ${ }^{2}$ with his individual actions.

Another interesting point which explains why ethical conduct is inseparable from others in society is that the human person is naturally a social being. Aristotle already spoke of this in the $3^{\text {rd }}$ century B.C. and this fact still stands today as is discoverable in contemporary writers in many fields both in philosophy and psychology and others. The fact of

${ }^{1}$ For more detailed explanation on the unified vision of life in narratives see Robert A. Gahl Jr., God in Dramatic Narrative, the article is published in Italian as "Etica Narrativa e Conoscenza di Dio" in Dio e il Senso dell'Esistenza Umana, Armando Editore, Roma, 1999, 189-202.

${ }^{2}$ According to Aristotle, above all things all humans seek happiness. Aristotle regards human life as consisting of aims and ends and describes the end at which all men ought to aim. He describes this end as eudaimonia and this word is usually translated as 'happiness'. Interpreters of Aristotle generally find this translation unsatisfactory as happiness in common language describes a feeling whereas Aristotle's eudaimonia means a certain kind of activity which is in accord with virtue. For more details see the introductory notes in Aristotle, Nicomachean Ethics, (translated by David Ross), Oxford University Press, Oxford, 1989. 
being situated among others and being constantly involved in interactions with the surrounding realities means that the human's actions affect other beings, both human and non-human realities that occupy the same space with him. This implies that ethical conduct affects other members of society and it is up to the individual to decide if such effects will be positive or otherwise.

This paper seeks to provide a theoretical background which demonstrates the importance of a narrative self understanding to perception of one's actions and how such awareness could affect the way one regards and treats others. The paper also presents empirical evidence to support these reflections.

To achieve this aim, the paper looks at the self narratives of twenty subjects vis-à-vis their perceptions of a common event (as a proxy of their judgements of others which therefore would influence their relations with others). It thus uses a qualitative method of textual analysis to examine the relationship between the way a person perceives and describes himself or herself and the way he or she perceives others. We expect that our study will throw some light into aspects that need to be included in curricula of managerial anthropology and of business ethics.

\section{Literature review and theoretical framework}

Both philosophers and psychologists have described the human life as a narrative. From the ethical point of view, human actions are also best understood when viewed within narratives. For Paul Ricoeur, a well know philosopher whose anthropology is imbued with ideas of narratives and temporality, narratives are the starting point for moral evaluations of human actions. ${ }^{3}$ The awareness of being the protagonist of building one's autobiography affects one's choices and actions. Maclntyre's thought coincides with Ricoeur's own. Maclntyre is perhaps the most important contemporary figure in narrative and philosophy. His works present an intersection of narratology, based on Aristotle, and Aquinas's thought. He states that "I can only answer the question 'What am I to do?' if I can answer the prior question 'Of what story or stories do I find myself a part?"' (Maclntyre, 1985, at 216) An agent's decision is made based on the general vision of the narrative he is constructing and what actions best suit him with regards to the construction of the type and genre of the narrative which he desires.

Another important aspect of the narrative self is that humans learn within their community. We humans learn from others around us, from their narratives and from interactions with them. MacIntyre (1985, at 134) affirms that within Aristotelian and ancient Greek thought, virtues have their place within a social context of the city-state and being a good person was considered to be allied to being a good citizen. The relationship between a person's autobiography and societal influence from another perspective has also been affirmed by Gahl (1999). He states that "the self awareness required for moral action involves three roles: that of the agent, that of the narrator and that of the audience." This implies that the self, even though he is author of his narrative, needs to observe others whose stories are intertwined with his. He learns from others and the stories of others, editing and reediting his own narrative based on things learnt from observing his audience and from being an audience for the narratives of other people.

In the same line, Maclntyre (1985, at 213) explains, "someone may discover (or not discover) that he or she is a character in a number of narratives at the same time, some of them embedded in others." Maclntyre $(1985$, at 218$)$ also affirms that "the narrative of any one life is part of an interlocking set of narratives." I am part of the stories of others and they are part of mine. According to Macintyre (1985, at 126), "identity in the heroic society involves particularity and accountability. I am answerable for doing or for failing to do what anyone who occupies my role owes to others and this accountability terminates only at death." Thus he also affirms that the society plays an essential role in the development of a person's narrative and that the person needs to be aware of his responsibility towards the other characters in the broader narrative pertaining to the historical society.

Another dimension associated to an autobiographical vision of the self includes that of wanting to leave an impact on the world; the construction of an autobiography that lasts beyond one's lifetime. Studies in psychology reveal that in mid-life, there is a tendency for a person to be concerned with the anticipated ending of the life story and such people may be moved to seek to give creative contributions to society. This concern for leaving a long-lasting legacy for future generations is described as generativity (McAdams and de St. Aubin, 1998) in contemporary psychology. "Generativity script (of personal myths) links the individual personal myths to the collective stories and myths of society as a whole and to the enterprise of promoting and improving human life and the welfare from one generation to the next" (McAdams, 1993, at 14).

\footnotetext{
${ }^{3}$ See Cervantes Barragán, Carácter y Promesa en la Forja de la Identidad, 32. Cervantes Barragán cites Paul Ricoeur's writings as basis for the analysis which she presents.
} 
These perspectives of the narrative self have been confirmed by much psychology research. Psychologists, Dan P. McAdams, Emma Mansour, Jonathan Adler, and many more have described the narrative structure of human life. There are also ongoing studies on the structure of human life.

Psychologist Csikszentmihalyi points out that, in order to reach flow, we need the help of others. Flow as a concept, is often referred to as "the Psychology of Optimal Experience" (Csikszentmihalyi, 1990). Optimal experiences are situations in which attention can be freely invested to achieve a person's goals. Flow is described as a state of consciousness in which a person's state of concentration so focused that it amounts to absolute absorption in an activity. It is often described as a phase in the human being's quest for happiness and fulfilment. Learning from the experiences or from stories of others is important to flow. Csikszentmihalyi citing Viktor Frankl's book: Man's Search for Meaning says that success, like happiness, cannot be pursued. It must ensue as the unintended side-effect of one's personal dedication to a course greater than oneself. The human being should be aware that he is not alone in his search for happiness. He should take the people around him into account in his quest, learning from them and also helping them in their own quest for happiness. If he does this, he is very likely to heighten his personal ethical sensitivity and this will enhance his capacity to be ethical in his choices.

\section{Methodology}

We are using a qualitative method akin to the case study approach. Thus we have collected twenty narratives of self and relating self to others. Thus each narrative could be considered as a case study. The subjects are young professionals interested in careers in management and therefore on the path to leadership positions. They are between the ages of 23 to 30 years old and have approximately 2 years of working experience on the average. The subjects were asked three questions designed to elicit self narratives with regard to self and with regard to others. The questions were:

1. Have you ever felt unable to understand someone? What happened?

2. Have you ever felt unable to understand yourself? What happened?

3. Can you describe your strengths and weaknesses?

The questions were deliberately designed to be only open-ended if the respondent was interested in narrating self. For each one, the respondent could simply answer 'no' and stop there. Or he or she could answer yes and go on to narrate a personal story. The freedom to tell or not tell a story helped to reduce the possibility of desirability bias. The event common to all is the experience of their inability to understand.

In analysing the content of the narratives, we ask ourselves four questions:

Who is speaking - trying to understand the self narrated individual characteristics of young people of a homogenous group with regard to nationality, age range, work experience and aspirations.

What is he or she saying - we attempt to identify commonalities and significant relationships in the communication content of the diverse persons,

Why is he or she saying this - we try to understand the narrators' understanding of others within the context of their self narratives.

How can these individual narratives affect the narrators' ethical sensitivity - we link the narratives with the degree of ease of ethical behaviour that a person will have in relation to his or her perception of self and others. We do this by comparing the results to the observations earlier made in the theoretical framework of the paper.

\section{Summary of Results}

\section{Similarities}

- 19 respondents felt there were times when they did not understand their own self.

- All 20 have found it difficult to understand others at some point in time.

- All respondents tell stories to respond to questions: including setting, time and then the major events that occurred.

- All respondents identify facts about others they would like to understand better.

- The respondents all placed importance to communication and interpersonal relation especially citing it either as a personal strength or weakness or in narrating events in which they did not understand.

A sample of summaries of the actual narratives is included as an appendix. Striking observations made while studying the narratives given by the respondents include the fact that the self narratives often made reference to other people with whom the respondents interact. It was also observed that the respondents tend to get along with people who 
have qualities which they have, admire or wish to have. One can infer that the perception they have of their selves or desires affect their assessment of people they interact with.

\section{Discussion}

It was interesting to see the respondents were able and willing to describe themselves with narratives. Each of them answered the questions with narratives of events and their experiences. The use of narratives to describe the self and also to describe others, as seen in the literature reviewed above was also noticeable in the responses received. In fact, one of the respondents expressed the need to understand why one tells "long stories" in order to express one's ideas. Such a respondent sees the self as a narrator but limits his narratives to specific episodes in life. A global vision of human life as a narrative would help such a person to have a better understanding of the self. One can infer that an inclusion of narratology in the curriculum of young professionals who have just begun to build their life stories could help their formation in anthropology and lay strong foundations for appreciating the principles of justice and fairness required to practice ethical behaviour. The philosophical notion that human beings are natural story tellers, supported by results of psychology research could be included in their curriculum. Thus, their attention could be drawn to the possibility of making a coherent meaningful life story with their actions and not only with their words, and in explaining events and their significance.

Another idea that is strongly present in the responses is that of the importance of understanding others. Respondent 3 affirmed that "being unable to understand someone can lead to wrong judgements and conflicts." Other respondents also identified the need to understand others. The responses all placed importance on the understanding others and having good interpersonal relations. The emphasis on good interpersonal relations was also seen in that when making the descriptions of personal strengths and weaknesses, the respondents made references to interpersonal relations and to interpersonal justice. For example, the responses all featured attitudes to team work and communication skills as part of the respondent's strength or weaknesses. These responses manifest the fact that life stories are intertwined. Life stories involve not only the protagonist but also other people who affect his stories. Also, having an understanding of a person's story can help understand his individual actions and this is important for interpersonal relationships.

It is also interesting to note that some of the respondents directly specified that self-understanding is needed in order to understand others. One could say that understanding one's life story, or personal (self) narrative, will help one understand the narratives of the others who's stories are intertwined with one's own.

Considering the fact that the respondents showed interest in improving their self-understanding, an introduction of narratology could help guide their personal development while including the concern for development of others and of the improvement of interpersonal relations.

Additionally, the awareness of each person's dependence on others was seen in the responses. For example one of the respondents used the famous quote "no man is an island" while explaining in the responding to the questions. This is definitely a useful viewpoint that would easily enrich discussions of concepts within the fields of ethics, leadership, social responsibility and sustainability.

\section{Conclusions}

Narrative self understanding is helpful for a proper evaluation of one's actions and relations with others. Also important for the narrative self is the need to develop society. All these topics as explained earlier are important to human fulfilment and are therefore important topics which could be included in the formation or education of managers and indeed every person.

The narratives analysed in this paper show the use of narratives in some way comparable to observations made in the theoretical framework given. Respondents identified the need to understand the self in order to be able to understand others. They also noted that they are narrators and that they learnt from the biographies of others and draw inspirations from them. Better understanding of these observed elements, which form part of a narrative self understanding, could help such managers get the best of themselves and of the totality of their life stories.

The findings reflect the need to draw people's attention to the fact that each person is creating his own narrative and can choose to direct it towards happiness. One sees that such awareness helps to foster consciousness of and development of responsibility to others for one's actions. Responsibility towards the development of other people could also be awoken in those people who are shown the perspectives of narrative self. 
A future study of the levels of self understanding and the understanding of others after attending courses on anthropology and or business ethics by the people who wrote the narratives used in this paper would be helpful for determining other elements which could be included in their curriculum.

\section{References}

Aquinas, T. (1972). Summa Theologiae, Prima Secundae (tr. \& ed. by Gilby, T. \& O'Brien, T.C.), Volumes 17, 18 and 27. Oxford: Blackfriars.

Aristotle, (1989). Nicomachean Ethics (tr. by David Ross). Oxford: Oxford University Press.

Csikszentmihalyi, M. (1990). Flow: The Psychology of Optimal Experience. New York: Harper Perennial.

Gahl Jr., R. A. (1999). Etica Narrativa e Conoscenza di Dio, in Dio e il Senso dell'Esistenza Umana. Rome: Amando Editore.

Gahl Jr., R. A. (2001). "Human Nature, Poetic Narrative, and Moral Agency. Jacques Maritain Center: Thomistic Institute.

Maclntyre, A. (1985). After Virtue: A Study in Moral Theory (2nd ed.). London: Duckworth Press.

Maclntyre, A. (1999). Dependent Rational Animals: Why Human Beings Need the Virtues. Chicago: Open Court.

MacIntyre, A. (1977). Epistemological Crises, Dramatic Narrative and the Philosophy of Science. The Monist, 60, 453-72. [Reprinted in Gutting, G. (Ed.) (1980). Paradigms and Revolutions: Appraisals and Applications of Thomas Kuhn's Philosophy of Science. Notre Dame: University of Notre Dame Press. pp. 54-74.]

MacIntyre, A. (1990). Three Rival Versions of Moral Enquiry. London: Duckworth.

Mansour, E. (2007). Developing a Life Story: Constructing Relations between Self and Experience in Autobiographical Narratives. Human Development, 50, 85-110.

McAdams, D. P. (1985). Power, Intimacy, and the Life Story: Personological Inquiries into Identity. Homewood: Dorsey Press.

McAdams, D. P. (1993). The Stories We Live By. New York: Guilford Press.

McAdams, D. P. (2006). The Redemptive Self: Stories Americans Live By. New York: Oxford University Press.

McAdams, D. P. (2008). American Identity: The Redemptive Self. The General Psychologist, 43(1), 20-27.

McAdams, D. P., Josselson, R., \& Lieblich, A. (2006). Identity and Story: Creating Self in Narrative. Washington DC: American Psychological Association.

McAdams, D. P., \& de St. Aubin, E. (1998). Generativity and Adult Development: How and Why We Care for the Next Generation. Washington DC: APA Press.

Appendix: Sample of Responses

\begin{tabular}{|c|c|c|c|}
\hline SN & Self perception & Perception of others & Comments \\
\hline 1 & $\begin{array}{l}\text { Sees self as a storyteller, uses long narratives } \\
\text { to answer questions and want to know why } \\
\text { Strengths includes patience, communication, } \\
\text { supportive } \\
\text { Discussed strengths and weaknesses in } \\
\text { relational terms i.e. he basically gives answers } \\
\text { which are an analysis of interactions with others }\end{array}$ & $\begin{array}{l}\text { Wants to know why others can have profound } \\
\text { effects on self } \\
\text { Likes people who give to others and are willing to } \\
\text { make sacrifices for them, dislikes selfish people }\end{array}$ & $\begin{array}{l}\text { Identifies link between } \\
\text { self understanding and } \\
\text { understanding other }\end{array}$ \\
\hline 2 & $\begin{array}{l}\text { Wants to understand "why my desires are } \\
\text { infinite" and why he's unsatisfied with victories, } \\
\text { always wanting more } \\
\text { Is an energetic "goal getter" } \\
\text { Describes strengths and weaknesses with } \\
\text { reference to his goals and abilities in quests for } \\
\text { seeking fulfilment and also those related to } \\
\text { interpersonal relationships }\end{array}$ & $\begin{array}{l}\text { Puzzled about betrayals and People who don't } \\
\text { admit comradeship or who are not happy about } \\
\text { the good fortune of others } \\
\text { finds interpersonal relationships very important. } \\
\text { Likes people with good communication skills and } \\
\text { interpersonal relationships, and loyalty } \\
\text { Dislikes people who have poor interpersonal } \\
\text { relationships }\end{array}$ & $\begin{array}{l}\text { Identifies a link between } \\
\text { his self perception and } \\
\text { how he treats others }\end{array}$ \\
\hline 3 & $\begin{array}{l}\text { Feels the need to love the self in order to love } \\
\text { others } \\
\text { He is Concerned about being understood by } \\
\text { others and wants to understand others }\end{array}$ & $\begin{array}{l}\text { Identifies the need to understand others in other } \\
\text { to have good interpersonal relationships } \\
\text { Identifies that human desires and wants are } \\
\text { unlimited and s puzzled by this } \\
\text { Likes hardworking people who also know how and } \\
\text { when to play dislikes opposite }\end{array}$ & \\
\hline 4 & $\begin{array}{l}\text { Prides self achievements and cites example of } \\
\text { how he helps others } \\
\text { Respondent is self motivated and determined. }\end{array}$ & $\begin{array}{l}\text { Describes self as "blunt" with management skills } \\
\text { but would like to change that } \\
\text { Likes people who have contributed to his life and } \\
\text { dislikes those who have offended him in one way }\end{array}$ & $\begin{array}{l}\text { Identifies the need for } \\
\text { the help of others in } \\
\text { order to succeed but } \\
\text { lays emphasis on the }\end{array}$ \\
\hline
\end{tabular}




\begin{tabular}{|c|c|c|c|}
\hline & & or another & $\begin{array}{l}\text { need for self motivation } \\
\text { self confidence }\end{array}$ \\
\hline 5 & $\begin{array}{l}\text { Does not recall any significant lack of self- } \\
\text { understanding } \\
\text { Expresses some of her strength and } \\
\text { weaknesses in terms of relation with others }\end{array}$ & $\begin{array}{l}\text { Likes people who care about and support others } \\
\text { Dislikes people with poor interpersonal } \\
\text { relationships (e.g. who are proud, snobbish or } \\
\text { unforgiving) }\end{array}$ & $\begin{array}{l}\text { Puzzled about people's } \\
\text { lack of concern for } \\
\text { others }\end{array}$ \\
\hline 6 & $\begin{array}{l}\text { Accepts that, even though such occasions are } \\
\text { rare, there are times he doesn't understand } \\
\text { himself. Does not understand why he is } \\
\text { naturally concerned about others especially } \\
\text { when such people do not show equal zeal for } \\
\text { shared projects }\end{array}$ & $\begin{array}{l}\text { Likes people who can focus on the future and } \\
\text { bring about change } \\
\text { Dislikes people who are unconcerned about } \\
\text { others or who do not value others. }\end{array}$ & $\begin{array}{l}\text { Puzzled about why } \\
\text { human beings long for } \\
\text { change but finds it } \\
\text { difficult to undergo } \\
\text { changes. }\end{array}$ \\
\hline 7 & $\begin{array}{l}\text { Self confidence built with self knowledge. A } \\
\text { person should learn to make the most of } \\
\text { himself and to do this he needs self knowledge. }\end{array}$ & $\begin{array}{l}\text { Puzzled about human being's insatiable desires } \\
\text { Likes people with good interpersonal relationships } \\
\text { Dislikes dishonest people and those with bad } \\
\text { interpersonal relations }\end{array}$ & $\begin{array}{l}\text { Affirms that self } \\
\text { understanding is } \\
\text { important for } \\
\text { understanding others }\end{array}$ \\
\hline 8 & $\begin{array}{l}\text { Interested in choosing a suitable career which } \\
\text { provides a goal towards which he can direct his } \\
\text { life } \\
\text { Sees self as a good team worker and a leader } \\
\text { Expresses interest in helping others }\end{array}$ & $\begin{array}{l}\text { Puzzled about how people can attempt to follow } \\
\text { two opposing life principles. } \\
\text { Encourages sincerity with self and with others } \\
\text { Likes people who are hardworking and who } \\
\text { motivate and help others } \\
\text { Dislikes people who are lazy, dishonest and who } \\
\text { lack respect for other people }\end{array}$ & $\begin{array}{l}\text { Has dynamism inspired } \\
\text { by the biographies of } \\
\text { successful business } \\
\text { men }\end{array}$ \\
\hline 9 & $\begin{array}{l}\text { Describes self as confident friendly and } \\
\text { describes personal strengths mostly with } \\
\text { reference to relating with others }\end{array}$ & \begin{tabular}{|l|} 
Puzzled about human affectivity, love and why \\
people stick to things that make them suffer \\
Discovers motivation from other people \\
Finds it difficult to get along with some people who \\
have ideas which are significantly different from \\
hers
\end{tabular} & $\begin{array}{l}\text { Identifies link between } \\
\text { self development and } \\
\text { relations with others }\end{array}$ \\
\hline
\end{tabular}

